\title{
ASSESSMENT OF CASE STUDY METHOD IMPLEMENTATION IN THE BUSINESS ENGLISH TEACHING
}

\section{Angela Strelchonok ${ }^{1}$}

\begin{abstract}
The paper presents research carried out with the purpose to evaluate the results of case study method implementation in the Business English language classroom with undergraduate students of RISEBA University of Business, Arts, and Technology.

The research question is whether students who are taught Business English through case studies develop better linguistic competence as well as greater proficiency in both language and business communication skills than students who are taught without the use of case study method.
\end{abstract}

An experiment was conducted on two equal groups during one academic semester. Each group was administered tests devised by the lecturer before and after the experiment. Data were analysed using statistical ANOVA methodology and evidence to support the hypothesis was obtained.

The results of statistical analysis confirmed the hypothesis about the advantage of implementation of the case study method in the Business English language classroom.

UDC Classification: 81-13; DOI: http://dx.doi.org/10.12955/cbup.v6.1250

Keywords: case, method, assessment, teaching

\section{Introduction}

The purpose of the paper is to raise the quality of Business English teaching not only by relating work done in the Business English classes to school curriculum but also by linking it to industry and business of the real world. The objective of Business English course is to develop and enhance students' Business English language competences in understanding and participating in a wide range of social or work-related discussions, case studies, interacting in work- or business-related communications, thus increasing students' motivation. If students believe that in a language course they do tasks relevant for their future professional communication, they are more motivated to learn. (Donna, 2000).

To achieve this aim a case study method was selected as an example of a Task-Based Learning (TBL) approach, which focuses on communicative approach towards problem-solving tasks presented in authentic case studies. Being a learner-centered approach, it views language as a communicative tool used to solve real-life situations.

There is now a substantive and growing body of literature describing how to develop and use case studies in management studies. Case study teaching has gained a strong foothold in science education. Research methodology in language learning has been described by such authors as Nunan (1992), Donna (1991), Brown and Rodger (2002), Porte (2002), etc. However, current research on the effectiveness of the implementation of the case study method in teaching Business English is of limited scope.

\section{Theoretical background.}

A task-based approach to language learning first appeared in the 1980s. It was analysed and described by such researchers as Candlin and Murphy (1987), Prabhu (1987), Nunan (1989, 2004), Skehan (1996), Willis J. and Willis D. (Willis, 1996, Willis, 2007), Ellis (2000), etc. The term "task" has been defined by many researchers. A task is an activity where the target language is used by the learner for a communicative purpose (goal) in order to achieve an outcome (Willis et al., 1996). The focus in the task is on meaning not on form. TBL provides learners with natural exposure (input), chances to use language to express what they want to mean (output), to focus on improving their own language as well as to analyse and practise forms. TBL is more likely to keep learners motivated since it builds on whatever language they know in a positive way. Learners are actively engaged throughout the task cycle, get chances to think for and express themselves in the security of their group. They are more autonomous and feel empowered, gaining satisfaction from successfully achieving things through language (Willis et al., 2007). Nunan states that task is a piece of classroom work which involves learners in comprehending, producing or interacting in the target language while their attention is principally focused on meaning rather than form. (Nunan et al., 1989). Pedagogically, task

\footnotetext{
${ }^{1}$ RISEBA University of Business, Arts, and Technology, Riga, Latvia, str@apollo.lv
} 
based language teaching has strengthened the following principles and practices: a needs-based approach to content selection, an emphasis on learning to communicate through interaction in the target language, the introduction of authentic texts into the learning situation, the provision of opportunities for learners to focus not only on language but also on the learning process itself, an enhancement of the learner's own personal experiences as important contributing elements to classroom learning, the linking of classroom language learning with language use outside the classroom (Nunan et al., 2004). Skehan outlines four criteria of a task: meaning is primary, there is some sort of relationship to comparable real-world activities, task completion has some priority, the assessment of tasks is in terms of outcome. (Skehan et.al., 1998). To conclude, the main advantages of TBL are that language is used for a genuine purpose meaning that real communication should take place, and that at the stage where the learners are preparing their report for the whole class, they are forced to consider language form in general rather than concentrating on a single form. The range of tasks available (reading texts, listening texts, problem-solving, role-plays, questionnaires, etc) offers a great deal of flexibility in this model and should lead to more motivating activities for the learners (Bowen, 2002). Jane Willis identified seven types of speaking and writing tasks which can successfully be used in the Business English classroom, among which are problem solving tasks: case studies, real-life problems, negotiations, etc.

\section{Case study method.}

One hundred years ago, Harvard Business School initiated a novel approach to teaching called the case study method. Patterned after the use of cases in its law school, the business faculty started using true stories of business practices to instruct students. In the classroom, students analyzed the details of a business problem with the professor in a Socratic dialogue. This methodology became known as the case method and is commonly practiced in that form today in graduate schools of law, public policy, and business. (Herreid, 2011, 2005) defines case studies as stories with an educational message. He adds that it is the stories that hook us. A well-told story will be remembered and with it the educational message. Business cases are usually dilemma cases. The students are asked to place themselves in the shoes of the decision maker. The case method involves learning by doing, the development of analytical and decision-making skills, the internalization of learning, learning how to grapple with messy real-life problems, the development of skills in oral communications and often teamwork. It is a "rehearsal for life" (Herreid, 2007). The goal in most case method teaching is not so much to teach the content of science, but to teach how the process of science works and to develop higher-order skills of learning and higher-order reasoning skills (Herreid et al., 2007). Gragg (1953) stressed that the purpose of case teaching is to develop analytical and decision-making skills. Erskine, Leenders and Mauffette-Leenders (1981, cited in Herreid 2007) noted that students are developing in the classroom a whole set of skills of speaking, debating and resolving issues. They are also gaining a sense of confidence in themselves and relating to their peers.

For this work a case study is defined as a teaching tool, which forces students into real-life situations that need to be solved. Daly (Daly, 2002) mentions numerous advantages of using case studies in the Business English language classroom:

- to develop critical thinking and reflective learning in the learner.

- to improve the student's organisational skills - as case studies are sometimes very dense in information, the key is to condense this information into logical sections and organise them so that a clear picture of the problem/issue can be understood

- to enhance communication skills - case studies can be used to improve the student's written and oral communication. Non-verbal communication skills are also practised by using case studies

- to train managerial communication skills such as holding a meeting, negotiating a contract, giving a presentation, etc. Case studies force students into real-life situations to require them to get involved in managerial communication.

- to encourage collaborative learning and team-working skills in the language learner.

Students are faced with real world tasks and given the authority to decide how to solve business problems using the target language they have already acquired at Business English classes and knowledge of subject areas gained in special courses. Rodgers (2006) stresses that this method allows 
the students to expand their repertoire of communication skills by requiring them to develop presentation, teamwork, and networking skills, as well as critical/analytical problem-solving skills. All of which are required in a modern business context characterized by a task force or team approach. It is a useful task-based activity representing the student-centered approach. In comparison, the traditional teacher centered method involves an instructor who is the hub, in which all communication goes through him or her. Learning a language and communication skills requires active participation. If only one student can speak at a time, how much learning can be accomplished? With the case study method, on the other hand, students are allowed to communicate in their individual groups, thereby multiplying the opportunities to produce language and to be corrected, as well as to practice communication skills (Rodgers, et.al., 2006).

There is a big difference between case studies used in other disciplines and language case studies. The former may be 10-40 pages long and the content is the key element of the case study, the correctness and details of which are emphasized. The latter are short, content is less detailed and is of minor importance. The content of language case studies is a tool and the language becomes the objective of the activity. Results are assessed mainly for their linguistic competence. Such famous authors of „Market Leader" series of pre-intermediate, intermediate, upper intermediate and advanced course books as David Cotton, David Falvey and Simon Kent (Cotton, 2010a,b, 2011a,b) as well as Mark Powell with Ron Martinez and Rosi Jillet ( Powell, 2004) and Tonya Trappe with Graham Tullis (Trappe, 2005,2006) integrated mini cases and/or dilemmas at the end of each chapter dealing with specific business topic, whereas John Allison with Mark Powell (Allison, 2005) collected 28 realistic Business English case studies in a separate book which is part of the "In Company" series. "Business Roles 1 and 2" (Crowther-Alwyn, 1997, 2007) are very valuable resource books containing numerous simulations with prescribed roles for students of Business English. David Evans (Evans, 2003) offers 14 business situations for analysis and discussion, Marjorie Rosenberg (Rosenberg, 2005) created activities with the element of fun, Paul Emmerson (Emmerson, 2007) suggests interesting topics for discussion and provides numerous activities for teaching business communication skills, Adrian Wallwork ( Wallwork, 1997a,b) wrote very valuable books for intermediate and advanced students containing many topic-based discussions. All these teacher resource books have been successfully used in the Business English classroom.

\section{Development of language and business communication skills.}

Usually a case has 5-6 stages during which students' language competencies and business communication skills can be practiced and developed.

- $\quad$ Case study introduction;

Students may be given to read the case in advance. The questions and discussion points provide a means for the teacher to check that students have understood the key points.

While reading the case, students are taught a considerable amount of language through interesting and stimulating content, they make connections between the language and what they already know within the context of a specific academic subject. They develop linguistic competence by consolidating already acquired and being introduced to new lexis. Students feel motivated as complex information is delivered through real life context based on a natural business situation. Brinton views the target language largely as the vehicle through which subject matter content is learned rather than as the immediate object of study (Brinton, 1989).

\section{- $\quad$ Defining the problem;}

Students discuss the situation in the company, analyze and discuss quantitative data, make SWOT analysis and present company goals. At this stage students start using the language as a communicative tool. Trying to identify a problematic situation encountered by the company, they develop analytical skills as well as reflective and critical thinking.

\section{- $\quad$ Problem solving;}

Students are divided into groups of 4-5 students to analyse the problems and find corresponding solution. Students participate in a meeting or negotiation to focus on finding a solution to the problem. In case of a meeting, a chairperson is selected to lead the meeting and an agenda is drawn up. Students 
should take detailed notes during the meeting. They identify options open to the company, evaluate the options, select the best option and draw up an action plan.

Trying to solve company problem(s) in groups or during a meeting enables students to develop managerial skills such as teamwork, decision-making and problem-solving. They practice and develop a variety of business communication skills relating to agreeing and disagreeing, checking understanding and clarifying information, discussing advantages and disadvantages, justifying proposals and reaching agreement, hedging, expressing opinions, interrupting, referring back, making one's point, making recommendations, inviting people to speak, opening and closing the meeting, etc. If we take negotiations as an example, students practice and develop the language used to put forward a proposal, agreeing and disagreeing with a proposal, imposing conditions, making concessions, asking for clarification, summarising what has been said, postponing a decision or playing for time, concluding a deal, etc. Students also develop organizational skills and collaborative learning .

- $\quad$ Presenting the solution(s);

After finding a solution to the problem students make presentations in groups. Students practice and develop presentation skills, such as introducing the talk, indicating the structure and sequences of your talk, moving from one section of your talk to another, highlighting, summarising and inviting questions.

- $\quad$ Evaluating the solution(s);

Students discuss the different solutions. A consensus should be reached on the main points raised in the presentations. Students develop the skills of finding a compromise, coming to a consensus.

- $\quad$ Follow-up (Optional);

As a follow-up activity students can be asked to write a letter, memorandum, a report, an e-mail, etc. They develop writing competence by taking the minutes, writing the agenda of the meeting, writing follow-up activities. Business English materials, which have structured and lexical approach to business skills (Emmerson et al., 1999a,b,c, Mascull, 2002, Goodale, 1997), have been successfully used in the Business English classroom for practicing and developing students' communication skills.

\section{- $\quad$ Feedback}

When the students are engaged in a fluency activity, it is better for the teacher to circulate unobtrusively, making language notes. At the end of the discussion the teacher feeds back the language by writing selected language points in context one by one on the board giving students a chance to supply words or correct mistakes first. When students give presentations the teacher may write individual feedback sheets for students, making it easier for them to review their mistakes out of class (Emmerson et al., 2007). Instead of leading the class, the teacher's role becomes that of a discussion facilitator who monitors discussions and provides the students with vocabulary, grammatical structures and content feedback.

\section{Methodology.}

To assess the validity and effectiveness of implementation of the case study method in Business English teaching, the research was conducted on RISEBA second-year undergraduate students of Business Administration programme during one academic semester (4 months). The research question was whether students who are taught Business English through the case study method develop better Business English language competencies and Business communication skills than students who are taught through traditional methods. An experiment was conducted on two groups during one academic semester. Each group was administered two pre-treatment and post-treatment tests before and after the experiment. Data were analysed by application of an one-way analysis of variance ANOVA and evidence to support the hypothesis was obtained.

\section{Participants.}

All 46 second-year students were randomly assigned to two groups: experimental and control, 23 students in each group. At the beginning of the semester each group was administered two pre-tests: speaking and vocabulary. Speaking and vocabulary tests were devised by the lecturer and included business topic areas and business vocabulary, which both groups had mastered during the first year of their studies. The speaking test was devised in compliance with the qualitative criteria presented by 
the Council of Europe. Both tests were assessed according to the 10-point scoring system implemented in RISEBA.

\section{Data collection and analysis.}

The results showed that the experimental group had the following values for averages of pre-tests: speaking -6.52 , vocabulary - 6.35, whereas the control group had values of 6.30 and 6.09 respectively. Pearson correlation coefficients between experimental and control groups in the speaking pre-test was 0.88 ; vocabulary -0.91 , which testifies to the fact that the two groups were almost equal.

Students of experimental group were taught using the case study method while students of control group were instructed through traditional methods.

At the end of the semester two post-treatment tests: speaking and vocabulary were administered in both groups. Test results were analysed applying ANOVA methodology and are shown below.

Table 1. Anova: Single Factor Experimental group. Speaking test

\section{SUMMARY}

\begin{tabular}{lrrrrrr}
\multicolumn{1}{c}{ Groups } & Count & Sum & Average & Variance & & \\
\cline { 1 - 5 } Pre-treatment test & 23 & 150 & 6.52 & 1.35 & & \\
Post-treatment test & 23 & 187 & 8.13 & 0.75 & & \\
\cline { 1 - 5 } ANOVA & & & & & & \\
\cline { 1 - 5 } \multicolumn{1}{c}{ Source of Variation } & SS & df & MS & F & P-value & F crit \\
\hline Between Groups & 29.76087 & 1 & 29.76087 & 28.25328 & 0.000003 & 4.061706 \\
Within Groups & 46.34783 & 44 & 1.05336 & & & \\
& & & & & & \\
Total & 76.1087 & 45 & & & & \\
Source: Author & & & & & & \\
\hline
\end{tabular}

It can be seen from Table 1 that the significance level P-value is 0.000003 , which shows that there is a statistically significant difference between pre- and post-treatment speaking test scores of the experimental group.

Table 2. Anova: Single Factor Experimental group. Vocabulary test

\section{SUMMARY}

\begin{tabular}{|c|c|c|c|c|c|c|}
\hline Groups & Count & Sum & Average & Variance & & \\
\hline Pre-treatment test & 23 & 146 & 6.35 & 1.24 & & \\
\hline Post-treatment test & 23 & 178 & 7.74 & 0.75 & & \\
\hline \multicolumn{7}{|l|}{ ANOVA } \\
\hline Source of Variation & SS & df & MS & $\mathbf{F}$ & P-value & F crit \\
\hline Between Groups & 22.26087 & 1 & 22.26087 & 22.43825 & 0.000023 & 4.061706 \\
\hline Within Groups & 43.65217 & 44 & 0.992095 & & & \\
\hline Total & 65.91304 & 45 & & & & \\
\hline Source: Author & & & & & & \\
\hline
\end{tabular}

As demonstrated in Table 2, the significance level P-value is 0.000023 . The result suggests that there is a statistically significant difference between pre- and post-treatment vocabulary test scores of the experimental group. 
Table 3. Anova: Single Factor Control group. Speaking test

SUMMARY

\begin{tabular}{|c|c|c|c|c|c|c|}
\hline Groups & Count & Sum & Average & Variance & & \\
\hline Pre-treatment test & 23 & 145 & 6.30 & 1.49 & & \\
\hline Post-treatment test & 23 & 161 & 7.00 & 1.00 & & \\
\hline \multicolumn{7}{|l|}{ ANOVA } \\
\hline Source of Variation & SS & df & MS & $\mathbf{F}$ & P-value & F crit \\
\hline Between Groups & 5.565217 & 1 & 5.565217 & 4.462758 & 0.040352 & 4.061706 \\
\hline Within Groups & 54.86957 & 44 & 1.247036 & & & \\
\hline Total & 60.43478 & 45 & & & & \\
\hline Source: Author & & & & & & \\
\hline
\end{tabular}

It can be seen from Table 3 that the significance level P-value is 0.040352 . The result suggests that there is a statistically significant difference between pre- and post-treatment speaking test scores of the control group.

Table 4. Anova: Single Factor Control group. Vocabulary test

\section{SUMMARY}

\begin{tabular}{|c|c|c|c|c|c|c|}
\hline Groups & Count & Sum & Average & Variance & & \\
\hline Pre-treatment test & 23 & 140 & 6.09 & 1.17 & & \\
\hline Post-treatment test & 23 & 155 & 6.74 & 1.11 & & \\
\hline \multicolumn{7}{|l|}{ ANOVA } \\
\hline Source of Variation & SS & df & MS & $\mathbf{F}$ & P-value & $F$ crit \\
\hline Between Groups & 4.891304 & 1 & 4.891304 & 4.282007 & 0.044422 & 4.061706 \\
\hline Within Groups & 50.26087 & 44 & 1.142292 & & & \\
\hline Total & 55.15217 & 45 & & & & \\
\hline Source: Author & & & & & & \\
\hline
\end{tabular}

As shown in Table 4, the significance level P-value is 0.044422 . It indicates that there is a statistically significant difference between pre- and post- treatment vocabulary test scores of the control group.

Table 5. Anova: Single Factor Between Experimental and Control group. Speaking test SUMMARY

\begin{tabular}{|c|c|c|c|c|c|c|}
\hline Groups & Count & Sum & Average & Variance & & \\
\hline Post-treatment test_Exp & 23 & 187 & 8.13 & 0.75 & & \\
\hline Post-treatment test_Control & 23 & 161 & 7.00 & 1.00 & & \\
\hline \multicolumn{7}{|l|}{ ANOVA } \\
\hline Source of Variation & SS & df & MS & $\mathbf{F}$ & P-value & F crit \\
\hline Between Groups & 14.69565 & 1 & 14.69565 & 16.74775 & 0.000179 & 4.061706 \\
\hline Within Groups & 38.6087 & 44 & 0.87747 & & & \\
\hline Total & 53.30435 & 45 & & & & \\
\hline Source: Author & & & & & & \\
\hline
\end{tabular}

The result of the analysis of post-treatment speaking test scores between the two groups: experimental and control has the significance level P-value of 0.000179, which testifies to the fact that there is a statistically significant difference between post-treatment speaking test scores of both groups. 
Table 6. Anova: Single Factor Between Experimental and Control group. Vocabulary test. SUMMARY

\begin{tabular}{|c|c|c|c|c|c|c|}
\hline Groups & Count & Sum & Average & $\begin{array}{c}\text { Varianc } \\
\text { e } \\
\end{array}$ & & \\
\hline Post-treatment test_Exp & 23 & 178 & 7.74 & 0.75 & & \\
\hline Post-treatment test_Control & 23 & 155 & 6.74 & 1.11 & & \\
\hline \multicolumn{7}{|l|}{ ANOVA } \\
\hline Source of Variation & SS & df & MS & $\mathbf{F}$ & P-value & F crit \\
\hline Between Groups & 11.5 & 1 & $\begin{array}{r}11.5 \\
0.92885\end{array}$ & 12.38085 & 0.001021 & $\begin{array}{r}4.06170 \\
6\end{array}$ \\
\hline Within Groups & 40.86957 & 44 & 4 & & & \\
\hline $\begin{array}{l}\text { Total } \\
\text { Source: Author }\end{array}$ & 52.36957 & 45 & & & & \\
\hline
\end{tabular}

The result of the analysis of post-treatment vocabulary test scores between two groups: experimental and control has the significance level P-value of 0.001021 , which proves that there is a statistically significant difference between post-treatment vocabulary test scores of both groups.

\section{Findings.}

The findings revealed that, as a result of case study method implementation at Business English classes, experimental group average scores of the speaking test increased by $24.67 \%$ and average scores of the vocabulary test improved by $21.92 \%$. The control group, which was instructed through traditional teaching methods, had average scores of the speaking test improvement by only $11.03 \%$ and of the vocabulary test by $10.71 \%$. Thus, when compared with the control group, the average scores of the speaking test obtained for the experimental group increased by $13.64 \%$, while average scores of the vocabulary test improved by $11.21 \%$.

The research proved that students who were taught Business English through the case study method developed better Business English language competencies and Business communication skills than students who were taught through traditional methods. Therefore, the case study method proved to be more effective than conventional teaching methods.

\section{Recommendations.}

Based on the findings, it is recommended that the case study method should be adopted for the instruction of Business English in higher institutions.

\section{References}

Allison, J., Powell, M. In Company Case studies. Oxford: Macmillan, 2005.

Bowen, T. Task-Based Learning. One stop English website. Available from Internet: http://www.onestopenglish.com, 2002.

Brinton, D. M., Snow, M. A., \& Wesche, M. B. Content-based second language instruction. New York: Newbury House, 1989.

Brown,J.D.,Rodger T.S. Doing Second Language Research. Oxford University Press, 2002.

Candlin, C., Murphy D. Language learning tasks. Englewood Cliffs, NY: Prentice Hall, 1987.

Comfort, J; Revell, R.; Stott, C. Business Reports in English. Fifteenth Edition. Cambridge: Cambridge University Press, 1998.

Cotton, D.; Falvey, D.; Kent, S. New Edition Market Leader. Pre-Intermediate Business English Course Book. Sixth Edition. Harlow: Pearson Longman, 2010a.

Cotton, D.;Falvey, D.; Kent, S. Intermediate Market Leader. Business English Course Book. Third Edition. Harlow: Pearson Longman, 2010b.

Cotton, D.; Falvey, D.; Kent, S. Upper-Intermediate Market Leader. Business English Course Book. Third Edition. Harlow: Pearson Longman, 2011a.

Cotton, D.; Falvey, D.; Kent, S. Advanced Market Leader. Business English Course Book. Third Edition. Harlow: Pearson Longman, 2011b.

Crowther-Alwyn, J. Business Roles 1. Cambridge: Cambridge University Press, 1997. 
Crowther-Alwyn, J. Business Roles 2. Third Edition. Cambridge: Cambridge University Press, 2007.

Daly,P.Methodology for using case studies in the business English language classroom. Internet TESL Journal. 8(11), 2002. http://iteslj.org/Techniques/Daly-CaseStudies/

Donna,M.Johnson.Approaches to Research in Second Language Learning. Longman,1991.

Donna, S. Teach Business English. Cambridge: Cambridge University Press, 2000.

Ellis, R. Task-based Language Learning and Teaching. Oxford: Oxford University Press,2000.

Emmerson, P. Business English Frameworks. Third Edition. Cambridge: Cambridge University Press, 2007.

Emmerson, P. Business Builder. Modules 1, 2, 3. Intermediate Teacher's Resource Series. Oxford: Macmillan, 1999a.

Emmerson, P. Business Builder. Modules 4, 5, 6. Intermediate Teacher's Resource Series. Oxford: Macmillan, $1999 \mathrm{~b}$.

Emmerson, P. Business Builder. Modules 7, 8, 9. Intermediate Teacher's Resource Series. Oxford: Macmillan, 1999c.

Evans, D. Decisionmaker. Fourth Edition. Cambridge: Cambridge University Press, 2003.

Goodale, M. The Language of Meetings. Eighth Edition. Hove: Language Teaching Publications, 1997.

Gragg, C.I., Because wisdom can't be told. In Andrews R.K., The case Method of Teaching Human Relations and Administration, 3-12, Cambridge, MA: Harvard University Press, 1953.

Herreid, C.F. Using Case Studies to Teach Science. American Institute for Biological Sciences, 2005. online at: http://actionbioscience.org/education/herreid.html

Herreid, C.F. Start With a Story. Arlington, VA: National Science Teachers Association Press, 2007.

Herreid, C.F. “Case study teaching,” New Directions for Teaching and Learning, 1 (128), 31-40, 2011.

Nunan, D. Designing tasks for the communicative classroom. Cambridge: Cambridge University Press, 1989.

Nunan, D. Research Methods in Language Learning. Cambridge: Cambridge University Press, 1992.

Nunan, D. Task-Based Language Teaching. Cambridge: Cambridge University Press, 2004.

Mascull, B. Business Vocabulary in Use. Cambridge: Cambridge University Press, 2002.

Powell, M.; Martinez, R.; Jillet, R. New Business Matters. London: Thomson Heinle, 2004.

Porte,G.K. Appraising Research in Second language learning. John Benjamins Publishing Company, 2002.

Prabhu, N. Second Language Pedagogy. Oxford: Oxford University Press, 1987.

Rodgers, D. Business Communications. International Case Studies in English. Sixth Edition. Cambridge: Cambridge University Press, 2006.

Rosenberg, M. In Business. Cambridge: Cambridge University Press, 2005.

Skehan, P. A Framework for the Implementation of Task-based Instruction. Applied Linguistics 17:38-62

Strelchonok, A. (2012). Development of Business English Language Communicative Skills

7th International Scientific Conference "Business and Management" Publication, Vilnius, Lithuania. Retrieved from http://www.bm.vgtu.lt ( Tomas Reuters )

Strelchonok, A.,Ludviga, I. (2013). The use of case studies in the business English language teaching. Social and Natural Sciences Journal, vol.7, No 1. Retrieved from http://ojs.journals.cz/index.php/SNSJ/article/view/414

Taylor, S. Communication for Business. Third Edition. Harlow: Pearson Longman, 1999.

Trappe, T.; Tullis, G. Intelligent Business. Coursebook. Intermediate Business English. Harlow: Pearson Longman, 2005.

Trappe, T., Tullis, G. Intelligent Business. Coursebook. Upper Intermediate Business English. Harlow: Pearson Longman, 2006.

Wallwork, A. Discussions A - Z Advanced. Cambridge: Cambridge University Press, 1997a.

Wallwork, A. Discussions A - Z Intermediate. Cambridge: Cambridge University Press, 1997b.

Willis, J. A Framework for Task-Based Learning. Harlow: Pearson Longman, 1996.

Willis, D.; Willis, J. Doing Task-Based Teaching. Oxford: Oxford University Press, 2007. 